The Logic of Miracles 
This page intentionally left blank 


\title{
THE LOGIC
}

OF MIRACLES

\author{
MAKING SENSE OF RARE, \\ REALLY RARE, AND \\ IMPOSSIBLY RARE EVENTS
}

\author{
$\triangle$ \\ LÁSZLÓ MÉRŐ \\ TRANSLATED FROM THE HUNGARIAN \\ BY MÁRTON MOLDOVÁN \\ TRANSLATION EDITED BY DAVID KRAMER
}

\section{Yale \\ UNIVERSITY PRESS}

New Haven and London 
Published with assistance from the foundation established in memory of Amasa Stone Mather of the Class of 1907, Yale College.

Copyright (C) 2018 by László Mérő and David Kramer. All rights reserved. This book may not be reproduced, in whole or in part, including illustrations, in any form (beyond that copying permitted by Sections 107 and 108 of the U.S. Copyright Law and except by reviewers for the public press), without written permission from the publishers.

Yale University Press books may be purchased in quantity for educational, business, or promotional use. For information, please e-mail sales.press@yale.edu (U.S. office) or sales@yaleup.co.uk (U.K. office).

Set in Adobe Garamond and Gotham types by Newgen North America. Printed in the United States of America.

\section{Library of Congress Control Number: 2017955615 ISBN 978-0-300-224I5-3 (hardcover : alk. paper)}

A catalogue record for this book is available from the British Library.

This paper meets the requirements of ANSI/NISO Z39.48-I992 (Permanence of Paper). 